\title{
A Study of Selected Works of Iranian Female Novelists Based on Elaine Showalter's Gynocriticism
}

\author{
Mojgan Eyvazi (Corresponding author) \\ English Department, Payam-e-Noor University, P.O. Box:19395-4697, Tehran, Iran \\ E-mail: mehkade@gmail.com \\ Mohsen Momen \\ Literature Department Payame Noor University, P.O. Box: 19395-4697, Tehran, Iran \\ E-mail: reera1348@yahoo.com \\ Homa Poorkaramali \\ English Department, Payam-e-Noor University, P.O. Box:19395-4697, Tehran, Iran \\ E-mail: hpourkaram46@yahoo.com
}

Received: 13-12-2016

Accepted: 17-03-2017

Advance Access Published: April 2017

Published: 01-07-2017

doi:10.7575/aiac.ijalel.v.6n.4p.211

URL: http://dx.doi.org/10.7575/aiac.ijalel.v.6n.4p.211

\begin{abstract}
Iranian literature, like other literary works throughout the world, follows the social issues in society and attempt to depict them. One of such issues is portraying women position in the society. The present study focuses on three different novels by Iranian female writers to show three stages of female writing development in them based on Elain Showalter's theory of gynocriticism: Feminine stage which is represented through concepts like home, immovability, consumption, reading, house chores, dependence and past, feminist stage dealing with concepts like mobility, production, independence and future, and female stage that presents a new awareness of women consciousness. The chosen works are: Hangover Dawn (1995) by Fataneh Haj Sejed Javadi that portrays the tragic life of a woman who insisted on marrying a person who is not a suitable match for her. The author has shown the pains that this woman has to suffer because of her wrong choice in patriarchal society. The next novel is titled Don't Worry (2008) by Mahsa Moheb Ali which deals with the life of an addicted girl named Shadi. She is the main character whose life is corrupted by family issues. Shadi wanders throughout the streets to find drug and ironically herself. My Bird (2002) by Fariba Vafi shows the life of an anonymous married woman who is stuck in her matrimonial life. The woman is neglected and cheated by her own husband. However, gradually she can come to a realization of her own self as a woman and redefines her own role. Having analyzed these three stories, it can be said that these three chosen novels match Showalter's model of female writing development. It can be concluded that Hangover Dawn follows the first stage feminine stage - Don't Worry follows the second stage - feminist stage - and My Bird follows the third stage - female stage - that Showalter has proposed.
\end{abstract}

Keywords: Feminine, Feminist, Female, Hangover Dawn, Don't Worry, My Bird

\section{Introduction}

Throughout many centuries and most cultures, humankind could have access to privilege, power, and language; however, the amount of their benefit could be determined by their biological features. If they were male, they would acquire the major share. Not only could men get more privilege in materialistic affairs; they enjoyed cultural, psychological, and religious superiority too. On the other hand, female used to be regarded as the other in society who could not have any proper access to the social resources. Such an attitude started from micro level to the macro level of social hierarchies. In the other words, it has been believed that the female oppression has been started from the families; "for centuries, and all over Europe, there were families who disposed of 'unnecessary' or unmarriageable daughters by shutting them away in convents" (Walters, 2005). The idea of female oppression has penetrated into all layers of society among both educated and uneducated people even the most educated people like "Aristotle [who] declared that 'the female is female by virtue of a certain lack of qualities; and St. Thomas Aquinas believed that woman is an 'imperfect man'."(Seldon, et all., 2005)

To solve this sexual discrimination and stand for the women's rights, a new movement started to shape. After feminism started to shape as a social movement which fights for female equality, many drastic changes took place in different fields. Literature has been an important media that was influenced by this social movement and a new literary trend for reading literary works shaped which was called feminist criticism. Feminist criticism comes in literary world in many forms and feminist critics have various goals. In this literary trend, how women are treated is analyzed and highlighted. 
The patriarchal system required women to be domestic, submissive, and silent creatures. Moreover, they should have been also "accomplished, demure and pious"( Peterson, 1984). To stand for the rights of women, feminism emerged as a system of thought for female expression. This system has challenged all the ideologies regarding the stereotypes of women. According to Wilfred et al. "feminism is an overtly political approach and can attack other approaches for their false assumptions about women"( Wilfred, et all., 1996).

As it has been mentioned, this movement contained different fields particularly literature and literary criticism and it examined how women had been depicted in literature as Tyson claims that "broadly defined, feminist criticism examines the ways in which literature (and other cultural productions) reinforces or undermines the economic, political, social, and psychological oppression of women"(2006). Therefore, this movement became a weapon for women to show their existence since "feminist literary criticism advocates equal rights for all women (indeed, all people) in all areas of life..."( Bressler, 2006)

Feminist literary criticism must be seen as a function of a political movement for women's freedom which spread in Europe and America to revive political and social issues which are associated with women. According to some theorists, gender and politics are the most important determining factors in this movement. Politically speaking, women and men are considered different; "the way the experience and perspective of women have been systematically and fallaciously assimilated into the generic masculine, and of the need to correct this error"( Schweickart, 1989) must come to existence. Eventually, it can be said that feminism is an effort to bring insights from various female experiences.

Gender is an integral part of feminist study and it has been used in different. Thinkers and philosophers have attempted to distinguish gender identity from biological sex. Money \& Hampson defined the term gender as "what a person says or does to reveal that he or she has the status of being boy or girl, man or woman"(1955) Gender is a complex issue, and it refers to the styles of dressing, patterns of moving, and the behavior; it is not just related to the biology. In this situation, gender becomes the product of society in which it is shaped through social and cultural discourse.

According to traditional view, gender is linked to biology, so that there exists a binary with male and female as its parts. In this sense, gender is natural, innate, and stable since birth which means it could not be changed. This view is problematic and ambiguous since there are many cases that contradict this view. Lorber \& Farrell note "What stays constant is that women and men have to be distinguishable"(1991).Moreover, it has been argued that people are not born with behaviors and characteristics of being masculine or feminine, but gender identity is developed within a culture and society and is nurtured, and molded by the culture. People are expected to take action according to the norms within that culture, and are socialized and gendered in a way in which their identity shaped based on social codes.

According to Butler, there is no universality of gender which is innate and natural at the time of birth; rather, it is the process of becoming and change. Butler's theory of gender is to locate "the mechanism whereby sex is transformed into gender is meant to establish not only the constructedness of gender, its unnatural and non necessary status, but the cultural universality of oppression in nonbiologistic terms."(Butler,1990) Accordingly, gender is defined as "an identity tenuously constituted in time, instituted in an exterior space through a stylized repetition of acts."(Ibid)

A woman's life is bound from all sides and parental and personal relationships are linked together. Women writers have had to come out of subordinate structures and the male style of thought. They have had to put away their submission, and fight back the male rules. Throughout their own writing, Women started to know and discover themselves. Women's writing has given power to them as Snitow said, "woman is my slave name . . feminism will give me freedom to seek some other identity altogether"(1990) Women's writing has been affective through self-expression and self-questioning and it has made a new definition of women. Their writing has attempted to break with patriarchy and move towards female meanings. The women of present generation started to show their own voice and feeling as independent members of society. It was during the feminist movement that the binary categorization of gender and sex came to importance. In the emergence of feminist criticism, gender has been recognized as "a crucial determinant in the production, circulation and consumption of literary discourse."( Ruther, 1983) According to Elaine Showalter:

It was through the women's liberation movement that we began to draw connections between our own work and our own lives, to note the disparities between the identifications and ambitions that had attracted us, along with thousands of other women, to the study and teaching of literature, and the limited and secondary aroles granted to fictional heroines, women writers or female scholars. Feminism spoke to our lives and our literary experience with the fierce urgency of a revelation or a great awakening. (1985)

The feminist writer attempts to analyze and realize the material conditions through which gender has been shaped within special languages. Gender has always been a significant term in feminist criticism. It referred to women and women's writing. All women's writing has been studied from feminist point of view which has been called Gynocriticism in which gender is a significant element. Ostriker writes: "writers necessarily articulate gendered experience, just as they necessarily articulate the spirit of nationality, an age, a language"(1986). The effects of gender and female sexuality can be seen throughout their works.

It is known that feminism is divided into three different waves with each emphasizing different aspects. One of the most significant books of Feminism is "Elaine Showalter's A Literature of their Own (1977), which provides a literary history of women writers. This book shows the model of female writing which is called gynocriticism, It is believes that she coined the term 'gynocriticism' for her mode of analyzing the works of women writers. She also argues for a 
profound difference between the writing of women and that of men and delineates a whole tradition of women's writing neglected by male critics.

Elaine Showalter is an influential American literary critic, feminist, and writer on cultural and social issues. She developed the concept and practice of gynocritics. Gynocriticism concerned with the specificity of women's experience and women's writing.

Showalter presents three important stages of women's writing. First, the imitation of the mainstream literary tradition: second, the protest against the standards of this dominant tradition and third, self-discovery which aims at a search for identity. Showalter identifies these stages as Feminine, Feminist and Female.

Elaine Showalter portrays development of women throughout the course of history. In her model of gynocriticism, she has mapped how women pass different stages in order to reach their own place in the society which is reflected in their writings. She believes that women at first used to be regarded as a passive member of society that patriarchal society oppressed them in different ways. However, later they realized that they should oppose and fight back the oppressive forces towards them. In the other words, at the beginning of the feminist movement, they learnt to be objective, challenge the ideological forces, and break with their own traditional image. Eventually, they can come to a realization of their real self in society. In fact, their awareness helps them to redefine their own roles as independent members of society. These three stages which are respectively titled feminine, feminist, and female show how women have reached their own place in society and acquired consciousness.

The above mentioned trend of gynocriticism is observable worldwide. Studying Iranian women`s literature can clarify different aspects of their social background. Published novels by women affect production, reproduction and identify change of Iranian women and power relations between men and women. These novels provide objective evidences to recognize society gender relation and current changes and one can trace a wider women's social movement through these lines of novels and uncover the structure of domination over women and their resistance against it. In this regard Showalter's view is an appropriate framework that can be used for analyzing gender studies in novels and the Iranian female writers' works have a great capacity to be investigated based on it to see how gender is represented in them.

\section{Method}

The present study analyzes some works of Iranian female writers based on Elaine Showalter's gynocriticism, which studies literature written by female writers inclusive of the interrogation of female authorship, images, the feminine experience and ideology, and the history and development of the female literary tradition. To do this three Iranian novels by Iranian writers are going to be focused on descriptively and analytically to see whether they follow Showalter's model of women writing namely feminine, feminist, and female writings. They are: Hangover Dawn (1995) by Fataneh Haj Sejed Javadi, Don't Worry (2008) by Mahsa Moheb Ali, and My Bird (2002) by Fariba Vafi.

\section{Discussion}

\subsection{Overview of Fataneh Haj Seyed Javadi and Hangover Dawn}

Fataneh Haj Seyed Javadi was born in 1945 in Kazerun and currently she lives in Isfahan. Her novel, Hangover Dawn, is one of the best-sold novels in Persian literature. The novel portrays the life of an aristocratic girl, Sudabeh, who insists on marrying a guy who is not as rich and cultural as her own family. To prevent this marriage, Sudabeh's mother refers her to her aunt to talk to her about her experience, so that she takes a lesson. Although the novel starts with Sudabeh, it shifts to the life of Sudabeh's aunt, Mahbub. Like Sudabeh, Mahbub, was from an aristocratic family; however, she chose a guy for marriage who is not from her social status. She is rejected from her own family and she experiences a lot of difficulties while married to her husband. In fact, as a woman, she is oppressed and becomes marginalized in patriarchal society. In the following section, how she is treated in the feminine stage will be shown.

\subsubsection{Feminine Writing in Hangover Dawn}

Showing women at home and restricting them to just inside be associated with reflection of a traditional woman in feminine stage. In patriarchal society, women are always locked at home and they are not allowed to go out of the house. Consequently, they are deprived of moving and mobility. In this stage of writing, home becomes a symbol for women, an integral one, from which they cannot be separated. Therefore, the author in this stage puts a significant emphasis on the reflection of home and highlights its role. This is what Javadi has done. She writes that "the house reflects the healthy taste and the gentle soul of the landlord"(Javadi, 1995). In this situation, "silence takes over" because women have been associated with silence.

The role of house becomes more important as the character says "I pray God that you are at this house"(Ibid). This statement is told to one of the characters since as a woman, being at home is the safest place for the character. Mahbub who is the main character of the novel and he is the oppressed person in this stage, refers to the importance of home. She says: "It was spring, and our house was filled with different plants and flowers. The inside and outside of the house were filled with different vases of flowers"(Ibid). What Mahbub here says shows that the place is very significant for family; therefore, the women in this family will be shown as the traditional figure that must be locked at home. Moreover, the author is highlighting the role of memory and flash backs which are the significant features of feminist stage. Showalter has mentioned "as the subject drew closer to home in time and space. Fictitious memoirs opened up a much more extensive area for the novelists to work in than if they had felt obliged to compose formal histories of recent times. Furthermore, the first-person document permitted free range to the emotions"( Showalter, 1972). 
What Showalter believes is that a traditional woman, like Mahbub, preserves the patriarchal version of woman in her mind; in fact, Mahbub's emotion and memories are to transfer ideologies of this patriarchal system to the other generations. This is the way that patriarchal system works and spreads in the society. In fact, Patriarchy is a social system that promotes hierarchies and awards economic, political and social power to one group over others. This kind of system just pays attention to one biological sex which is male and females are considered as the other in society. Therefore, this system signifies the subordination of females to males, but the "whole structure of Father ruled society: aristocracy over serfs, masters over slaves, kings over subjects, racial overlords over colonized people"(Reuther, 1983). Mahbub recalls her memories and her past in this kind of system that she used to live. She narrates the day when one family wanted to propose her for their son; she says how she was treated in that system as if the family wanted to buy her. How Mahbub was measured in this system shows the attitudes towards women. In fact, this treatment shows the feminine aspect of the novel that Showalter has mentioned:

How acceptable your daughter is... she kisses your hand...I did not like to kiss...I should smile so that they could see how organized and healthy my teeth were. How beautiful your teeth are they are like pearls...come here I want to kiss you lass. She took my arm and put kisses on my cheeks...she wanted to see whether I stink or not?...the results were all satisfactory since my mother mad me to wear a lot of perfume...I put my hands on my skirt and I looked down, and I answered the questions gently with yes or no... how obedient your daughter is! ( Javadi, 1995)

As it is known patriarchy refers to the domination of the male over the female and it is series of structures and ideologies that signify submissiveness and independence of women. Mahbub is shown as a submissive and obedient wife that must follow the rules in patriarchal system. Mahbub's opinion is not significant for the family in her own marriage since the father must decide whom she marries. This shows how submissive and obedient women were: "I have not seen him. I do not know how he looks. Should I marry him without seeing him? Even when he has a kid? It is none of your business. Your father should know him and of course he knows him well. It is not important that he has a kid"(Ibid). Javadi shows the role and importance of father in this system. In fact, since father possesses phallus, it can be regarded as the symbol of power and domination for him:

The process of symbolization itself as 'phallic'. It is through the Name-of-the-Father that the phallus is installed as the central organizing signifier of the unconscious. The phallus is the 'original' lost object, but only insofar as no one possessed it in the first place. The phallus, therefore, is not like any other signifier, it is the signifier of absence and does not 'exist' in its own right as a thing, an object or a bodily organ.( Lacan, 1975)

Javadi has tried to show the importance of men over women in this system of patriarchy. According to Showalter, a man "achieves the power and the dignity"(1988) over a woman. Mahbub admits her situation in that house as a submissive woman who is under pressure; therefore, she wants to "escape from that house as soon as possible...to be released from all the pressures"(Javadi, 1995).

What Mahbub says shows that she is in a situation in which her personality and ideas are oppressed by the patriarchal system and her father? In fact, the treatment of her father towards her shows her as a submissive and dependent woman since Mahbub reminds "my father told me as long as you are married to this guy, you cannot step in this house"(Ibid). Mahbub reminds of her own memories which were painful for her; as a woman, she had to be happy on her wedding night; however, she remembers how she felt because of all oppressive forces over her that made her obedient and independent: "That miserable and poor wedding, and this small house, and that painful and hard day of my wedding were all for me. I was like a deer in a dry and strange plain that wanders alone. I am followed by a hunter and heading down to a mysterious and unknown land. I was alone and heart broken. I was angry at my father, my mother and the world"(Ibid).

The oppression of women in the patriarch system is very long and from the beginning in ancient time, many thinkers have regarded women inferior to men. According to the classical system of patriarchy, the biological inferiority of woman makes her inferior also in her abilities, her ability to reason and, make decisions. Since man has superiority and woman has inferiority, man is born to rule and a woman must be obeyed. It is believed that "the courage of man is shown in commanding of a woman in obeying"(Lerner, 1989). For this reason, Mahbub regards herself as the inferior person in this society. She says that "I burst into tears. It is my fault. I broke my parents' heart. I am the reason that she cannot marry "(Javadi, 1995)..Mahbub is a role model of patriarchal system that is exposed to different oppressive forces in the society that she lives.

\subsection{Overview of Mahsa Moheb Ali and Don't Worry}

Mahsa Moheb Ali is an Iranian writer and a literary critic who was born in 1972 in Tehran. Her first collection of short stories was published when she was 26 years old. She has written two collections of stories and two novels. The story of Don't Worry deals with a young and addicted girl that is looking for drugs. The author has tried to reflect the problems and difficulties of this girl.

\subsubsection{Feminist Writing in Don't Worry}

Unlike the feminine phase in which women have been associated with home and immobility, and they were passive and exposed into oppression, in the feminist phase, women are shown to be active and play a more active role. In this phase, street and outside is in contrast with home and being inside. For the women, street and wandering become the desirable aim despite all the dangers that could be brought about. The main character of the novel, likes mobility and her interest for mobility could be seen in different situations. At the beginning of the novel, when she lied down on a bed, she says that "whenever my bed shook, I got happier, it was like a boat not like now which is similar to a coffin"(Moheb Ali, 
2008). In this example, the narrator compares her own bed to both a boat and a coffin. In fact, she associated features of mobility to her bed which made her happy. However, now her bed is like coffin which is associated with immobility. Consequently, the idea of death and life are challenged symbolically that shows the narrator wants to be mobile.

In the feminist stage which is associated with protesting and challenging patriarchal ideologies, women are shown to be mobile and active. The narrator of the novel does not escape from the great earthquake; rather, she goes to the streets and wonders "why so many people in Shariati street? as if all the world population lived in this street"(Ibid). She does not want to stay in just one place and she likes "to go up a place and see the all things"(Ibid). What the narrator says is that she wants to be "outside the dominant boundary and therefore"(Showalter, 1988) Unlike the feminine picture of woman who is associated with consumption, in femininst stage, a woman is related to production. The narrator used to be a musician who could compose and create. In fact, in this system, Ali has attempted to associates the female character of her novel with the power of creation. Therefore, this female character can have creative power unlike the traditional woman: "I picked up the bow. My hands are shaking...I cannot hear violion. Just my fingers are shaking and I am moving the bow... What am I playing?"(Moheb Ali, 2008). The narrator is shown to be as a productive woman which is different from that traditional woman who used to be associated with consumption. She plays a musical instrument, so that she has creative power.

The narrator is a woman who does not match with the traditional definition of a woman; she is different and she opposed any picture of obidient and submissive female. It is known that patriarchy is a system which conceptualizes and supports the natural and innate superiority of male over female, it is fond of women's dependence on, and subordination to, man in all spheres of life. Consequently, all the power and authority within the family, the society and the state are preserved for men. In this situation, subordination means, "something else is less important than the other thing"(Cobuild, 2010). The narrator does not want to be subordinated to the male society, she is a woman who breaks with conventions na traditions; therefore, what narrator does is completely in contrast with the traditional definition of a woman: "I smoke and I look at the street through the smokes. " (Moheb Ali, 2008)

She is in the sreets and she is wandering which is in contrast with being at home. The narrator is rebelious and she witnesses all the events around the street. She is not afraid of the streets and even earthquack which is used symbolically. She says:

The pipes start to shake. Everyone is screaming and freaking out. My legs are into the air and I am lying on the grass. I open my arms. Sky is coming around. I am like a cross attached to the earth...the shakings are talking to me...they are talking to me...it felt that it is the first time that I was lying on the grass. I smell the grass. My fingers are walking on the grass. The smell of rain, the smell of wetness, the smell of tree...I wish I could...go inside the earth and dance with it. The shakings walk through me....and I do not want them to be finished. (Ibid)

What she says shows that the narrator cannot confined to home and locked up in the house. She is example of a brave woman who is runnig away from passivity and home. The narrator does not walk as she said "I want to gallop to reach the bridge...I go forwards and backwards. I shovel...look at me...how many crazy people can you see in your entire life?"(Ibid) All the masculine features are associated with the narrotar. In fact, Mohb Ali shows the distinction between gender and sex. Although the narrator is biologically woman, what she does and how she behaves are not feminine. In fact, how she performs rejects the feminine picture of the narrator. Since gender can be defined as "a whole range of different symbolic activities, including style of dress, patterns of consumption, ways of moving, as well as talking."(Edley, 2001) the narrator cannot be regarded as that traditional woman. Gender identity is constructed and reproduced through these symbolic activities in a very broad sense. For this reason, the narrator does not follow the traditional image of a woman.

\subsection{Overview of Fariba Vafi and My Bird}

Fariba Vafi was born in Tabriz in northwestern Iran on January 21, 1963. Her first novel, My Bird, came out in 2002 and won the award for top novel from the Golshiri Foundation and Yalda Literary Award later in the same year. In 2003 her Tarlan, a novel was published. Two years later, The Tibet Dream was released, for which she won the top prize of the Golshiri Foundation. Some of her short stories have been translated into Russian, Japanese, Swedish, Turkish, etc. She has won several awards and accolades from different literary events.

The novel of My Bird portrays the story of life, love, and the demands of marriage and motherhood, Fariba Vafi gives readers a portrait of one woman's struggle to adapt to the complexity of life in modern Iran. The narrator, a housewife and young mother living in a low-income neighborhood in Tehran, with her husband Amir who desires to immigrate to Canada. When he finally slips away,the young woman is forced to raise the children alone and care for her ailing mother.

\subsubsection{Female Writing in My Bird}

Showalter believes that in this phase, different aspects of being a woman can come to existence. This stage is associated with self-discovery and realization of their own gender. It is in this phase that women have understood that they are different from men and through such differences, they could develop and reach self-awareness. The physical differences that they have would make them experience, feel, and think uniquely: "In order to live a fully human life, we require not only control of our bodies ... we must touch the unity and resonance of our physicality ... so there is a kind of celebration of woman's body as a source of imagery in writers". Therefore,"women define and categorize areas of difference and similarity which in turn allow us to comprehend the world around us through language"(Shwoalter, 1986). 
The author shows that at first the woman in this novel did not have any activity and self-awareness. The narrator suffers from loneliness since his husband just thought about going to Canada.

Physically, he is at home, mentally he is away, neglecting his wife's feelings and needs. Living in his own world, he neither sees nor hears her. This life in loneliness and silence reminds the wife of her childhood in silence with a strict father and a bitter mother. She is not particularly in love with her husband, but she is not strong enough to leave him either. Therefore, she continues to live with him, while keeping silent about her true feelings about Amir. (Vafi, 2002)

However through her own imagination and mentality, she can release herself from this marriage and think about her own desires as a woman. The narrator says:

Amir does not know that I betray him one hundred times a day; when I pick up his pajamas left on the floor, precisely as he has taken them off; when at our parties, he is so busy with other people that he does not even think of me [...]; when he looks at me as the reason behind all his failures. He does not know that I leave this marriage one hundred times a day [...] for places that he cannot even imagine. Then, in the darkness of a night like this, I return to this house and to Amir like a penitent woman. (Ibid)

As the story develops, so does the main character's personality. Once she puts her head on Amir's chest, she thinks about their marriage and condition; she breaks from that traditional woman she used to be and moves towards independence: "I come closer to Amir and put my head on his chest. His chest is too hard. I put my head a bit lower. Amir caresses my hair [...]. He cannot even imagine how tired I am of him"(Ibid). The narrator has to go through a complex process in order to reach the self-discovery that every woman wishes for; she experiences "carelessness from the husband... and the society as well"(Zanusi, 2013). Therefore, she decides to experience her own liberation; however, she is tried to be prevented from such feeling. "I feel the liberation and I talk about it, but Amir does not let me to express such an important word about such trivial and unimportant sentiments".(Vafi, 2002)

In this novel, the main character wants to acquire her own identity through liberal thoughts that she wants to have. She wants to face her own female part in a context which is free from any patriarchal ideologies; she is neither submissive nor protesting; she wants to be free, therefore, "she is no longer frightened by patriarchal traditions and founds her relationship with the opposite sex upon human feelings and passions, and values the counterpart as much as she does herself"(Saeidian \& Hosseini, 2013) She is the character who has gone through a complete transformation from a traditional woman to a modern woman whose role has been redifined, and her fears as well as her silence are gone; she admits "that very moment I thought about my silence. It was like a rental dress that my attention was suddenly directed to"(Showalter, 1986).

The female stage shows the place that a woman can reach at the end through self-contemplation; she can express what she feels as Showalter believes "feelings of alienation from male predecessors...their culturally conditioned timidity about self-dramatization, their dread of the patriarchal authority of art, their anxiety about the impropriety of female invention." (Ibid) All can be worked out, if a woman trusts herself and her nature. on this condition, she can know that she has her own potential that must be found and cherished as in the case of the main character of My Bird; eventually, she remarks "The one whose bird flies away from a place, it hardly can stay in the same place. The bird becomes a stranger in its own place. Do I have a bird? My own bird"(Vafi,2002). This statement shows the self-awareness that the main chracter has reached.

\section{Conclusion}

Having analyzed all of these three novels from Showalter's point of view, it can be said that each of these novels is based on Showalter's model of gynocriticism which regards three stages for female writings. The first novel, Hangover Dawn by Fataneh Haj Sejed Javadi, portrays a traditional woman who is victim of patriarchal society. she is rejected and oppressed by her father, her husband, and her social class. The author has highlighted the imobility, submissivity, obidience, and independence of the main character, Mahbub. The concepts of home and past are very important for her. Thus, Hangover Dawn has been written based on feminine writing.

The second novel, Don't Worry by Mahsa Moheb depicts a female character who is rebellious and does not give up to the patriarchal and traditional image of a woman. The author associates the female character with mobility, protesting, independence, and street. She breaks with her traditional picture. Therefore, the novel of Don't Worry has been written based on femininst model of writing.

My Bird portrays a woman's life and her daily relationship with her children and her husband which is boring for her. However, she starts to redifine "her relationships with her husband, family and children in her mind through a loud and anxious monologue"(Saeidian \& Hosseini, 2013). Although she is "passive against the events taking place...she contemplates them in the mind" (Rezvanian \& Kiani, 2015) and finally she can reach her own true self and identity through the symbol of her own bird. Therefore, the novel of My Bird has been written based on female writing.

\section{References}

Bressler, Charles E. (2006). .Literary Criticism: An Introduction to Theory and Practice. New Jersey: Prentice Hall Inc.

Butler, J. (1990). Gender Trouble: Feminism and the Subversion of Identity. New York: Rutledge.

Callaghan, D. (2000). A Feminist Companion to Shakespeare. New Jersey: Blackwell Publishers Ltd.

Cobuild, C. (2010). Advanced Illustrated Dictionary. New York: Harper Collins Publishers Ltd. 
Dusinberre, J. (1994). Shakespeare and the Nature of Women. London and New York: Rutledge.

Edley, N. (2001). Discourse as Data A Guide for Analysis. London: Sage Publications Ltd.

Javadi, F. (1995). Hangover Dawn. Tehran: Nashr Alborz.

Lacan, J. (1975). "The Ego in Freud' and in the Technique of Psychoanalysis". The Seminar of Jacques Lacan, Book II, edited by J.A. Miller, Cambridge: Cambridge University Press.

Lerner, G. (1989). The Creation of Patriarchy. New York: Oxford University Press.

Lorber, J. \& S. A. Farrell. (1991).The Social Construction of Gender. California: Sage Publications Inc.

Moheb Ali, M. (2008). Don't Worry. Tehran: Nashr Cheshmeh.

Money, J., \& Hampson, J. ((1955).“Hermaphroditism: Recommendations Concerning Assignment Of Sex, Change Of Sex, And Psychologic Management”. Bulletin of the Johns Hopkins Hospital, 97, 284 - 300.

Ostriker, A.S. (1986). Stealing the Language: The Emergence of Women's Poetry in America. Boston: Beacon Press.

Peterson, M. J. (1984). "No Angels in the House: The Victorian Myth and the Paget Women." The American Historical Review, 89(3), 677-708.

Reuther, R. (1983). Sexism and God-talk: towards a feminist theology. London: SPCK.

Rezvanian, Q., \& Kiani, H. (2015). "The Representation of the Identity of Woman in the Works of 1380s Female Story Writers”. Journal of Research Literature, 31, 39-63.

Saeidian, S. \& Hosseini, R. (2013). “A Sociological Study of Iranian Women's Role in Fictional Literature in the Recent Two Decades". International Journal of Women's Research, 2(2), 59-72.

Schweickart, P. (1989). Reading Ourselves: Toward a Feminist Theory of Reading, edited by Elian Showlter, London: Routledge.

Seldon, R., and Widdowson, P., and Brooker, P. (2005). A Reader's Guide to Contemporary Literary Theory. London: Edinburgh Gate.

Showalter, E. (1988). "Feminist Criticism in the Wilderness." Modern Criticism and Theory: A Reader, edited by David Lodge, London: Longman.

---. (1986). "Towards a Feminist Politics." Contemporary Literary Criticism: Modernism through Post Structuralism, edited by Robert Con Davis, New York: Longman Inc.

--- ed. (1985). The New Feminist Criticism: Essays on Women, Literature and Theory. New York: Pantheon Books.

--- (1972). The Evolution of French Novel. New Jersey: Princeton University Press.

Snitow, A. (1990). A Gender Dairy." Conflicts in Feminism, edited by Marianne Hirsch and Evelyn Fox Keller. New York: Rutledge.

Tyson, L. (2006). Critical Theory Today. New York: Rutledge.

Walters, M. (2005). Feminism: A Very Short Introduction. Oxford: Oxford University Press.

Wilfred, L. Guerin and Labor, Earle and Morgan, Lee and Reesman, Jeanne C. and Willingham, John R. (1996). $A$ Handbook of Critical Approaches to Literature. Oxford: Oxford University Press.

Vafi, F. (2002). Parande-ye man (My Bird). Tehran: Nashr-e Markaz.

Zanusi, S. (2013). A Thematic Analysis of My Bird, Scientific Information Database, Accessed September 4,. http://www.sid.ir. 